\title{
Reveal the Prevalence of Anti-Hepatitis B Core and its Importance among Hemodialysis Patients in Hodeidah City
} E.M.El-Morsy ${ }^{1}$, A.A.El-baially ${ }^{2}$, S.M.Alghalibi ${ }^{3}$, M.E.Khalifah ${ }^{1}$ and K.A.Baddah $^{4}$

${ }^{1}$ Botany, Dept., Faculty of Science, Damietta Univ., Damietta, Egypt

${ }^{2}$ Microbiology and Immunology, Dept., Faculty of Medicine, Zagazig Univ., Zagazig, Egypt

${ }^{3}$ Microbiology and Immunology, Dept., Faculty of Science, Sana'a Univ., Sana'a, Yemen

${ }^{4}$ Medical laboratories, Faculty of medicine and health Sciences, Hodeidah Univ., Hodeidah, Yemen

E.mail:baddahkhaled_2007@yahoo.com

\begin{abstract}
Hepatitis B is a dangerous illness and simple blood transportation and other ways, particularly in patients with chronic hemodialysis (HD). HBV has significant pathogenicity and mortality rates. The objective of this experiment was to assess the rates of anti-HBc distribution among chronic HD patients in Hodeidah City. This investigation was applied to 150 chronic HD patients and soon before HD sessions, samples were obtained. All samples have been analysed using ELISA for anti-HBc. Sera, which has shown that anti-HBc is positive, were tested for liver function. The ages of 30 to $50 \mathrm{y}$ (40,7 percent) were the most vulnerable and statistically significant to the HD process ( $\mathrm{P}<0,05)$. Of 150, 129 (86.0 percent) were anti-HBcAg positive. Conclusions: significant anti-HBc distribution rate among HD patients in the city of Hodeidah.
\end{abstract}

Keywords: chronic HD patients, Anti-Hepatitis B core (anti-HBc).

\section{Introduction}

Hepatitis B is a dangerous illness and simple blood and other ways of transport, particularly in patients with chronic hemodialysis $(\mathrm{CH})$. The HBV continues to be an enormous health burden that generates substantial morbidity and mortality $[1,2]$ and accounts for $96 \%$ of hepatitis C (HCV) death etiology[3]. Approximately 1.34 million people die from viral hepatitis annually, with mortality rate being greater than the HIV-related mortality [4]. A strategy has been devised by the World Health Organization (WHO) to eliminate chronic HBIs by 90 percent and reduce death to 65 percent by 2030 [5].

Chronic HD disease is an enormous problem in practically all societies, and in poorer areas it has increased dramatically[6]. Despite the fact that the prevalence of HBV in chronic HD patients declined significantly throughout past decades[7], the immunosuppression of HD patients is still a major clinical problem. All techniques in HD centres may play a leading role in HBV transmission unless they are correctly and accurately used. In the course of organ transplants [8], too. The inadequate reactions to the HBV vaccination were characterised by that group of patients which led to a more likely transmission of HBV and Occult Hepatitis B (OBI) [9, 10].

An internal, structural protein thus non-found in the blood, hepatitis B core antigen ( $\mathrm{HBcAg})[11,12]$. The presence of $\mathrm{HBcAg}$ is derived from its antibody in the serum of the patient, which is present even after recovery from the start of the infection. The $\mathrm{HBcAg}$ and the e antigen (HBeAg) share sequences, but do not interact $[11,13]$. Core protein has multiple role functions, for example I stimulating humoral immunity by anti-HBc, as well as cellular immunity when $\mathrm{HBcAG}$ peptide particles are found on the hepatic cell surface in order to stimulate immune cells to kill cells[14], (ii) tying HBV to covalently closed circular DNA (cccDNA).
HBsAg and/or anti-HBsAg may be affected by many factors arising from immune or molecular pathways affecting their presence in the blood of the patients. Anti-HBc is the initial antibody response to the infection of hepatitis B (HBI) and its presence may indicate: I acute or chronic HBI (ii), healing (iii) window time (21-23), (iv) OBI when no viral DNA detection technique is used[24], even although about $20 \%$ are negativ-anti-HBc [25]. Anti-HBc has gained significant attention, particularly in the absence of protective anti-HBs. Wang et al reported an anti-HBc alone, around $40 \%-70 \%$ of OBI[26].

Everyone carrying this serological mark is thus regarded as a carrier of the virus and may transmit it to other persons, both immunocompetent and immunocompromised[27-30].

The incidence of anti-HBc ranges between $6.2 \%$ and $35 \%$ [31]. In earlier decades, the prevalence of anti-HBc in HD patients in various nations was as follows: In Turkish [32], 30\% in Egypt [33], 2\% in Iran [34], 44.6\% in Iran [35], 49.1\% in Suez Canal, Egypt [363], 18.9\% at Al-Gharbia, Egypt [37], 17.55\% in Fatima Memorial Hospital, Lahore [31], 24.2\% in China [38] and 25\% (59/237) [39].

Healthy cells in the liver contain a normal amount of enzymes such as alkaline phosphatase (ALP) and other enzymes. The amount of alanine aminotransferase (ALT) in positive $\mathrm{HBeAg}$ is increased. In HBI the level of liver enzymes is modified, and the same alterations also present during pregnancy, leading to challenging recognition of the true cause in pregnant patients[40]. Treatment of chronic HBI with normal ALT should be based on both histology and HBV-DNA levels[41]. ALT increase may occur spontaneously or superadded in chronic HBI patients with other viruses or medications or for drug-inducing seroconversions[42]. In individuals with Fibrosis (12-43\%) without chronic HBI, normal ALT is seen [43]. Decrease in AST and 
ALT serum in individuals with HD owing to several variables shown in Figure (1) [44].

Although HBsAg screening test works in particular among HD patients with HBI detraction, there are nonetheless several reasons, for example mutations that impede $\mathrm{HBsAg}$ detection. In addition, non-molecular approaches and especially in emerging districts are difficult to discover these mutations, since HD patients are more harmful to infection transmission and may lead to cirrhosis and HCC [25, 45]. Furthermore, in Yemen, the high cost of PCRs does not enable routine testing in HD patients and sensitive PCRs, needed for OBI detection $(<200 \mathrm{IU} / \mathrm{mL})$ are not accessible. However, we can prevent the transfer of HBV or OBI in HD patients by anti-HBc tests in which particular treatment must be carried out for HD patients positive for anti-HBc. The aim of this research is to recognise the prevalence of anti-HBc among chronic HD patients in the city of Hodeidah.

\section{Patients and methods}

This study was conducted at the HD center in the city of Hodeidah, western Yemen, the capital of the Hodeidah governorate. Hodeidah city is the fourthlargest city in Yemen and away from the capital Sana'a with a distance of about 226 kilometers. This study was applied to 150 chronic HD patients.

\subsection{Inclusion criteria}

- Both sex (male and female)

- patients with end-stage renal disease on regular HD (at least for one year).

\subsection{Exclusion criteria}

- The patients infected with HCV

- other causes of liver dysfunction such as HIV infection, autoimmune hepatitis, primary biliary, and cirrhosis.

\subsection{Analysis of samples}

Blood samples were taken immediately before the HD session, aliquoted, and stored at a temperature of $-80^{\circ} \mathrm{C}$ until further analyses. All samples were tested for the anti-HBc by an automated ELISA (Cobas e 411 analyzer) method using the commercially available kits (Roche Diagnostics, Germany). The three liver enzymes level for 129 samples was measured by BioSystems BTS-330 using commercially available kits (Human Gesellschaft für Biochemica und Diagnostica mbH, Germany).

\subsection{Data Analysis}

Data were analyzed with SPSS version 21 . The normality of data was first tested with the one-sample Kolmogorov-Smirnov test.

\section{Results}

The sex and age distribution of 150 chronic HD patients and the data are summarized in Table 1. Out of 150 patients, $104(69.3 \%)$ were males and 46 $(30.7 \%)$ were females. Patients with ages ranging between 9 and 75 years with a mean \pm SD of 39.06 \pm 14.09 , were divided into three age groups; i) <30 years old, ii) 30-50 years of age, and iii) $>50$ years old. HD patients were 30 to $50 \mathrm{y}(40.7 \%)$ followed by $<30 \mathrm{y}(35.3 \%)$.

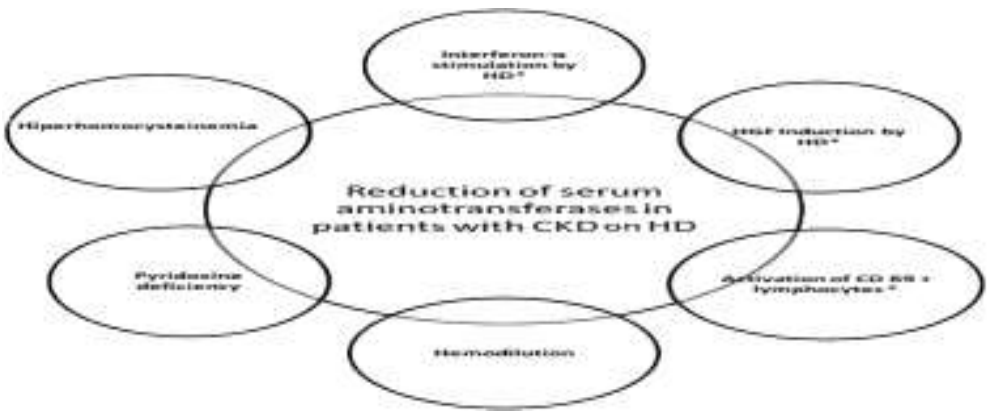

Fig. (1) Factors involved in aminotransferase reduction in patients with chronic kidney disease on hemodialysis.

Table (1) Demographic data of the studied group

\begin{tabular}{|c|c|c|}
\hline \multirow[t]{2}{*}{ Variables } & \multicolumn{2}{|c|}{ Study group $(n=150)$} \\
\hline & No & $\%$ \\
\hline \multicolumn{3}{|l|}{ Sex } \\
\hline Male & 104 & $69.3 \%$ \\
\hline Female & 46 & $30.7 \%$ \\
\hline \multicolumn{3}{|l|}{ Age/years } \\
\hline$<30 y$ & 53 & $35.3 \%$ \\
\hline $30-50 y$ & 61 & $40.7 \%$ \\
\hline$>50 y$ & 36 & $24.0 \%$ \\
\hline Mean \pm SD & \multicolumn{2}{|c|}{$39.06 \pm 14.09$} \\
\hline Range & & \\
\hline
\end{tabular}

The current study showed out of 150, 129 (86.0\%) were positive of anti-HBcAg (Fig 2). 


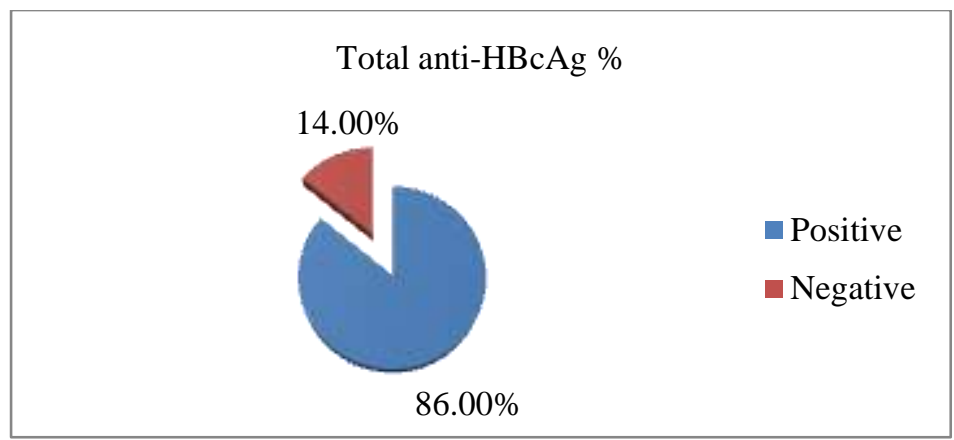

Fig. (2) Anti-HBcAg among the studied group

Out of 129 positive anti-HBcAg, 88 (68.2\%) and 44 (31.8\%) were male and female respectively. Also, the ages from 30 to 50 were more positively of anti-HBcAg. No significant statistical differences between anti- $\mathrm{HBcAg}$ and the sex and ages of the patients Table (2), Fig. (3), and Fig. (4).

Table (2) Relation between Total anti- HBcAg and demographic data

\begin{tabular}{|c|c|c|c|c|c|c|}
\hline \multirow[t]{2}{*}{ Variables } & \multicolumn{2}{|c|}{$\begin{array}{c}\text { Total anti- HBcAg p positive } \\
(\mathbf{n}=129)\end{array}$} & \multicolumn{2}{|c|}{$\begin{array}{l}\text { Total anti-HBcAg negative } \\
(\mathbf{n}=21)\end{array}$} & \multirow[t]{2}{*}{$\begin{array}{c}\text { Test of } \\
\text { significance }\end{array}$} & \multirow[t]{2}{*}{ p-value } \\
\hline & No & $\%$ & No & $\%$ & & \\
\hline \multicolumn{7}{|l|}{ Sex } \\
\hline Male & 88 & 68.2 & 16 & 76.2 & 0.54 & 0.462 \\
\hline Female & 41 & 31.8 & 5 & 23.8 & & \\
\hline \multicolumn{7}{|l|}{ Age/years } \\
\hline$<30 \mathrm{y}$ & 44 & 34.1 & 9 & 42.9 & 0.680 & 0.712 \\
\hline $30-50 y$ & 53 & 41.1 & 8 & 38.1 & & \\
\hline$>50 y$ & 32 & 24.8 & 4 & 19.0 & & \\
\hline $\begin{array}{l}\text { Mean } \pm \text { SD } \\
\text { Range }\end{array}$ & \multicolumn{2}{|c|}{$39.64 \pm 14.12$} & & $35.47 \pm 13.68$ & $* \mathrm{t}=1.26$ & 0.210 \\
\hline
\end{tabular}

$\chi^{2}$ : chi square test, $* \mathrm{t}=$ Student $t$ test

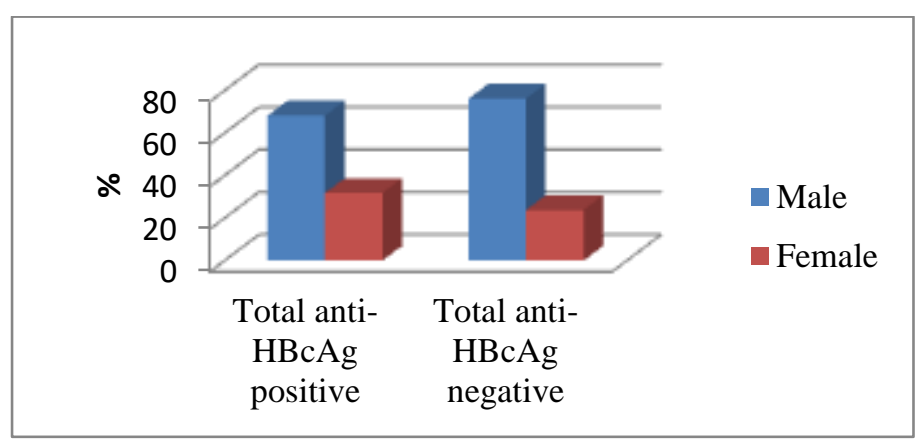

Fig. (3) Relation between Total anti- HBcAg and Sex

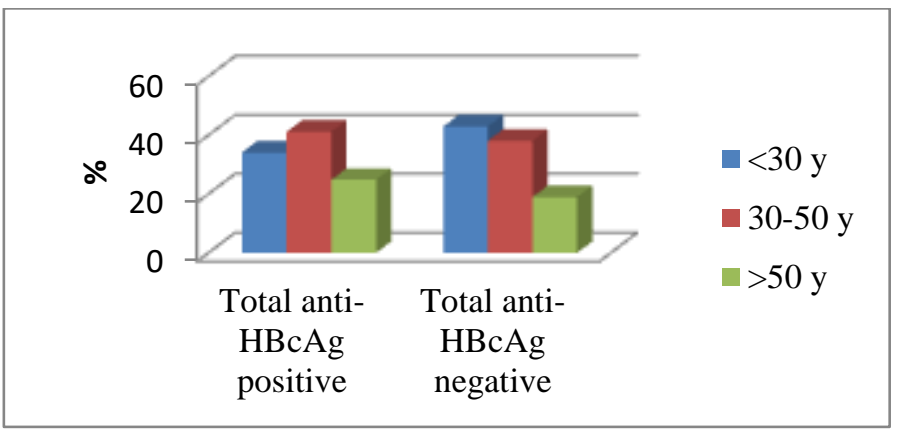

Fig. (4) Relation between Total anti- HBcAg and Age

Normal levels of ALT and AST showed in 117 patients (90.7\%) and 108 patients (83.7\%) respectively, whereas alkaline phosphatase (ALP) enzyme was abnormal in 90 patients $(69.8 \%)$, no statistically significant (Table 3 ). 
Table (3) Relation between Total anti- HBcAg and laboratory investigations.

\begin{tabular}{|c|c|c|c|c|c|c|}
\hline \multirow[t]{2}{*}{ Variables } & \multicolumn{2}{|c|}{$\begin{array}{c}\text { Total anti- } \mathrm{HBcAg} \\
\text { positive }(\mathrm{n}=129)\end{array}$} & \multicolumn{2}{|c|}{$\begin{array}{l}\text { Total anti- HBcAge } \\
\text { negative }(n=21)\end{array}$} & \multirow[t]{2}{*}{$\chi^{2}$} & \multirow[t]{2}{*}{ p-value } \\
\hline & No & $\%$ & No & $\%$ & & \\
\hline ALT & & & & & & \\
\hline Normal & 117 & 90.7 & 20 & 95.2 & 0.470 & 0.493 \\
\hline Abnormal & 12 & 9.3 & 1 & 4.8 & & \\
\hline AST & & & & & & \\
\hline Normal & 108 & 83.7 & 19 & 90.5 & 0.635 & 0.426 \\
\hline $\begin{array}{l}\text { Abnormal } \\
\text { ALP }\end{array}$ & 21 & 16.3 & 2 & 9.5 & & \\
\hline Normal & 39 & 30.2 & 6 & 28.6 & 0.024 & 0.878 \\
\hline Abnormal & 90 & 69.8 & 15 & 71.4 & & \\
\hline
\end{tabular}

\section{Discussion}

$104(69.3 \%)$ out of 150 patients were male and $46(30.7 \%)$ were female. Patients between 9 and 75 years of age with a mean \pm SD of $39.06 \pm 14.09$. HD patients were between 30 and 50 years (40.7 percent). These age groups were particularly exposed to and statistically significant in the HD process $(\mathrm{P}<0.05)$. That may be because of the hot climate and insufficient electrical support in this town, which results in increased perspiration followed by poor kidney function, therefore they are most prone to renal failure. In several China towns, HD was present in Shanghai (11.8\%) [46], Beijing (13\%) [47] and Tibet (19.1\%) [47] among patients 18 years old and older. In another research in Beijing, however, people over 40 years of age were subject to HD (11.3 percent)[49]. Furthermore, the sexually active character, illegal drug use, tattooing and corporal piercing of these individuals are risk factors for HBV transmission.

Of $150,129(86.0 \%)$ were anti-HBcAg positive. Recovery from past acute or chronic HBI[24] or OBI may be indicated. Similar anti-HBc findings were observed in $80 \%$ of HD patients [50, 51].

The prevalence of anti- $\mathrm{HBc}$ ranges from 6.2 percent to 35 percent[31]. Other results recorded HD patients in the Iranian government were I $44.6 \%$, (ii) $49.1 \%$ in the Suez Canal in Egypt and (iii) $18.9 \%$ in the Governorate of $\mathrm{Al}$ Gharbia in Egypt[37], (ii) $24.2 \%$ in China[38], and (iii) $25 \%$ (59/237) [39] respectively.

HD patients require frequent transfusions of blood and this may lead to the development of bloodborne disease serological markers, such as HBV anti-HBc, due to several factors, including use of the same machines for all patients, contaminated injection medication during preparation in HD rooms [52], common friction of infected patients and healthcare personnel, and weak HBV vaccinal response. While HBsAg screening assays work particularly between HD patients in HBI detraction, numerous reasons, such as mutations, hinder HBsAg detection. Detection of these mutations is challenging, especially in developing districts and non-molecular approaches, since HD patients are more dangerous and may lead to cyrrhosis and HCC [25, 45], However, any transfer of
$\mathrm{HBV}$, in particular via anti-HBcAg testing and proper handling of HD patients, may be avoided.

The high incidence of anti-HBcAg may contribute to our findings, in addition to the following explanations (1) HD patients with weak immunity, weak HBV vaccine response, (2) HBsAg mutations, (3) modest HD-patient facility and low-health precautions[53], (4) wartime war-time warfare, HD centre was lone in the governorate of Hodeidah, and it receives all HD patients from different areas in the Governorate, (5) war-related livelihood impacts, etc. Implementing anti-HBcAg and HBV NAT screening will make blood safer and minimise the occurrence of OBIs[55]. In Yemen, high PCR costs in HD patients are not permitted and the PCR sensitivity necessary $(<200 \mathrm{IU} / \mathrm{mL})$ may not generally be accessible for detecting OBI. In order to minimise transmission of and reactivation of hepatitis $B$ infection (HBI) in HD, these results should be considered and the appropriate therapy of anti-HBcAg-positive HD patients[9, 10, $56][57]$.

88 (68.2 percent) and 44 (31.8 percent) were both male and female out of 129 positive anti-HBcAg. In addition, the ages between 30 and 50 were higher anti$\mathrm{HBcAg}$ positive. No statistically significant variations between anti-HBcAg and the patients' sex and age (Table 2, Fig 3, and Fig 4). Anti-HBcAg was more common in men than in women because of disparities in their work. For example, men are working, barbershops are more visited and blood transfusion techniques are more engaged. In contrast, women mostly participate in domestic activities based on social, cultural and religious inclinations. As soon as the ages of 30 to 50 years are more experiencing HD so that anti-HBcAg and other blood-borne disorders might emerge more likely.

Although the frequency of anti-HBcAg was high, the normal levels of both ALT and AST were high in 117 patients $(90.7 \%), 108$ patients $(83.7 \%)$ and the normal levels of alkaline phosphatase (ALP) in 90 patients $(69.8 \%)$. (Table 3$)$.

Similar findings were typical for individuals with HBI with chronic renal disease, aminotransferase levels were normal values. In these patients, too, elevated levels of ALP. However, 30.7 (4/13) patients 
with positive anti-HBc alone reported Elghannam et al., while 33.3 percent $(9 / 27)$ of the positive patients with anti-HBc and anti-HBs had normal liver function test (LVT) levels[33]. Different CKD phases need distinct aminotransferase reference limits [58]. Reduction in HD patients' aminotransferases due to several factors such as I removal of aminotransferases during HD session, (ii) the occurrence of uremic factors that inhibit the activities of the enzymes, (iii) pyridoxine failure, cofactor for aminotransferase synthesis, (iv) nicotinamide adenine dinucleotide (NADPH) intakes [59, 60]; The liver, bone, gut and placenta are the initial locations of ALP production. Serum ALP level is an essential indicator for screening and monitoring in a patient with liver disease. However, renal osteodystrophy leads to an elevated amount of ALP in a CKD patient[62]. After HD, AST, ALT and ALP increase, although the contrary is before [63].

\section{Conclusion}

The incidence of anti-HBc in HD patients is high, and $\mathrm{HBV}, \mathrm{OBI}$, and molecular mutations are very often detected, owing also to other factors preventing HBsAg from being detected on blood. We must take into account the significant incidence of anti-HBc and the appropriate care of HD patients. The test against HBC should be a standard component of our HD population screening. PCR analysis may assist to reduce high $\mathrm{HBV}$ infection in HD patients by low-cost and high-sensitivity PCR.

\section{References}

[1] M. Blachier.The burden of liver disease in Europe: a review of available epidemiological data. J Hepato.vol.1583,pp. 593-608, 2013.

[2] G. Dultz, and S. Zeuzem, C, Hepatitis Virus: A European Perspective. Gastroenterol Clin North Am.vol.44(4),pp. 807-24. , 2015.

[3] I. Abubakar, T. Tillmann, and A. Banerjee, Global, regional, and national age-sex specific all-cause and cause-specific mortality for 240 causes of death, 1990-2013: a systematic analysis for the Global Burden of Disease Study Lancet.vol.385(9963),pp.117-171,2015.

[4] WHO, Global Hepatitis Report Geneva,vol.23,pp.147-150,2017.

[5] WHO, Combating hepatitis $\mathrm{B}$ and $\mathrm{C}$ to reach elimination by 2030: advocacy brief.vol.13,pp.255-270,2016.

[6] W.Prodjosudjadi, , Incidence, prevalence, treatment and cost of end-stage renal disease in Indonesia. Ethnicity and Disease.vol.16(2),pp.S2,2006.

[7] Alavian S.M., Hepatitis B and C in dialysis units in Iran: changing the epidemiology. Hemodial Int.vol. 12(3),pp.378-82. , 2008.

[8] G.D.Chen, . Outcomes and risk factors for hepatitis $\mathrm{B}$ virus $(\mathrm{HBV})$ reactivation after kidney transplantation in occult HBV carriers.
Transplant Infectious Disease.vol.15(3),pp. 300305, 2013.

[9] J.S.Motta. Occult hepatitis B virus infection and lamivudine-resistant mutations in isolates from renal patients undergoing hemodialysis. $\mathbf{J}$ Gastroenterol Hepato.voll25(1),pp. 101-6, 2010.

[10] S.H. Song, and S.G. Hwang, Occult hepatitis B virus infection: transmission and reactivation. The Korean Journal of Gastroenterology.vol.62(3),pp.148-153, 2013.

[11] W.Robinson, R. Webster, and A. Granoff, Hepatitis B Viruses. General Features (human). Encyclopaedia of VirologyAcademic Press Ltd., London.vol.22,pp.125:126,1994.

[12]F.J. Mahoney, M. Kane, Hepatitis B vaccine. Vaccines.vol.3,pp. 158-82,1999.

[13] W. Robinson, Hepatitis B Virus and Hepatiis D Virus. MANDEL, DOUGLAS, and BENNETT, $S$ Principles and Practice of Infectious Diseases.vol.14,pp144:146, 2000.

[14] C. Ferrari. Cellular immune response to hepatitis $B$ virus-encoded antigens in acute and chronic hepatitis B virus infection. The Journal of Immunology.vol.145(10),pp. 3442-3449,1990.

[15]C.T. Bock . Structural organization of the hepatitis B virus minichromosome. J Mol Biol.vol.307(1),pp. 183-96, 2001.

[16] S.Le Pogam . Exposure of RNA templates and encapsidation of spliced viral RNA are influenced by the arginine-rich domain of human hepatitis B virus core antigen ( $\mathrm{HBcAg} 165-173$ ). J Viro.vol.179(3),pp.1871-87, 2005.

[17] Lewellyn, E.B. and D.D. Loeb, The arginine clusters of the carboxy-terminal domain of the core protein of hepatitis B virus make pleiotropic contributions to genome replication. Journal of virology.vol.85(3),pp.1298-1309, 2011.

[18]Chu, T.H., Nucleic acid chaperone activity associated with the arginine-rich domain of human hepatitis $\mathrm{B}$ virus core protein. J Viro.vol.188(5),pp.2530-43, 2014.

[19] S. Le Pogam, and C.Shih, Influence of a putative intermolecular interaction between core and the pre-S1 domain of the large envelope protein on hepatitis B virus secretion. Journal of virology.vol.76(13),pp. 6510-6517, 2002.

[20]A. Zlotnick, , Core protein: A pleiotropic keystone in the HBV lifecycle. Antiviral Res.vol.121,pp. 82-93, 2015.

[21] Urbani, S., The role of anti-core antibody response in the detection of occult hepatitis B virus infection. Clinical chemistry and laboratory medicine.vol.48(1),pp.23-29, 2010.

[22] Ocana, S., Diagnostic strategy for occult hepatitis B virus infection. World J Gastroentero.vol.117(12),pp. 1553-7, 2011.

[23] S.-Y.Kang, M.-H. Kim, and W.-I. Lee, Occult hepatitis $\mathrm{B}$ virus infection in Korean patients with isolated anti-HBc. Archives of virology.vol.159(2),pp. 227-233. , 2014. 
[24] Raimondo, G., Statements from the Taormina expert meeting on occult hepatitis B virus infection. Journal of hepatology.vol.49(4),pp. 652-657, 2008.

[25] Makvandi, M., Update on occult hepatitis B virus infection. World J Gastroentero.vol.122(39),pp. 8720-8734, 2016.

[26] Wang, Q., Significance of anti-HBc alone serological status in clinical practice.vol.2(2),pp.123-134, 2017.

[27] C.S.Coffin . Persistence of isolated antibodies to woodchuck hepatitis virus core antigen is indicative of occult infection. Hepatology.vol.40(5),pp. 1053-1061, 2004.

[28] Manzini, P., Italian blood donors with anti-HBc and occult hepatitis $B$ virus infection. Haematologica.vol.92(12),pp. 1664-1670,2007.

[29]C.Kupski. Serologic and molecular profile of anti-HBc-positive blood bank donors in an area of low endemicity for HBV. Digestive diseases and sciences.vol. 53(5),pp.1370-1374, 2008.

[30]F.Vitale. Can the serological status of "anti-HBc alone" be considered a sentinel marker for detection of "occult" HBV infection? Journal of Medical Virology.vol.80(4),pp. 577-582, 2008.

[31] Tarif, N., Prevalence of Hepatitis B core antibodies with negative Hepatitis B surface antigen in dialysis and chronic kidney disease patients. Saudi Journal of Kidney Diseases and Transplantation.vol.28(4),pp. 869, 2017.

[32] Yakaryilmaz, F., Prevalence of occult hepatitis B and hepatitis $\mathrm{C}$ virus infections in Turkish hemodialysis patients. Ren Fail.vol.28(8),pp.72935, 2006.

[33], D.M . Elghannamet ., Clinical significance of antibody to hepatitis $B$ core antigen in multitransfused hemodialysis patients. Asian journal of transfusion science .vol .3(1),pp.14, 2009.

[34] Ramezani, A., Isolated anti-hbc and occult HBV infection in dialysis patients. Nephro-urology monthly.vol.7(1),pp. 16,2015.

[35] H.Keyvani. Prevalence and risk factors of isolated anti-HBc antibody and occult hepatitis B infection in hemodialysis patients: a nationwide study. Annals of hepatology.vol .12(2),pp. 213 219, 2015.

[36] Mandour, M., Occult HBV infection status among chronic hepatitis $\mathrm{C}$ and hemodialysis patients in Northeastern Egypt: regional and national overview. Revista da Sociedade Brasileira de Medicina Tropica .vol .148(3),pp.258-264, 2015.

[37] T.A.Elbedewy, S.A. Elshweikh, and N. Baiomy, Prevalence and significance of hepatitis-B core antibodies among hepatitis B surface antigennegative Egyptian patients on hemodialysis in Al-Gharbia governorate. Tanta Medical Journa.vol.144(2),pp. 33, 2016.
[38] N.Mooppil . P1456 PREVALENCE OF HEPATITIS B CORE ANTIBODY AND OCCULT INFECTION AMONG HAEMODIALYSIS PATIENTS. Nephrology Dialysis Transplantation35(Supplement_3), pp. gfaa142. P1456. , 2020.

[39] Bozaci, I. and S. Tosun, The Relationship of Hepatits B Core Antibody Positivity with Demographic and Laboratory Parameters in Hemodialysis Patients . vol . 12 ,pp. 149- 155 ,2021.

[40] O.A.Abulude, I.1. Ahmed, and F.U. Sadisu, Assessment of Hepatitis B Viral Infection as a Predictor of Hepatic Enzymes and Compounds Alteration among Antenatal Patients. Medical Sciences . vol .5(4),pp. $24,2017$.

[41] Amarapurkar, D., Management of hepatitis B viral infection with normal ALT. Hepatitis B Annual . vol .3(1),pp. 155, 2006.

[42] Perrillo, R.P., Acute flares in chronic hepatitis B: the natural and unnatural history of an immunologically mediated liver disease. Gastroenterology .vol.120(4),pp. 1009-22, 2001.

[43] Keeffe, E.B., A treatment algorithm for the management of chronic hepatitis B virus infection in the United States: an update. Clinical Gastroenterology and Hepatology . vol .4(8) ,pp. 936-962, 2006

[44] Sette, L.H. and E.P. Almeida Lopes, Liver enzymes serum levels in patients with chronic kidney disease on hemodialysis: a comprehensive review. Clinics (Sao Paulo). vol . 69(4),pp.271-8, 2014.

[45] Burns, G.S. and A.J. Thompson, Viral hepatitis B: clinical and epidemiological characteristics. Cold Spring Harb Perspect Med . vol .4(12),pp.024935, 2014.

[46] N. Chen Community-based study on CKD subjects and the associated risk factors. Nephrology Dialysis Transplantation . vol . 24(7),pp. 2117-2123, 2009.

[47] L.Zhang . Prevalence and factors associated with CKD: a population study from Beijing. American Journal of Kidney Diseases . vol .51(3),pp. 373$384,2008$.

[48] W.Chen . Prevalence and risk factors of chronic kidney disease: a population study in the Tibetan population. Nephrology Dialysis Transplantation . vol .26(5),pp. 1592-1599, 2011.

[49]L.Zhang . Community-based screening for chronic kidney disease among populations older than 40 years in Beijing. Nephrology Dialysis Transplantation . vol .22(4),pp. 1093-1099 , 2007.

[50]F. Hollinger, and G. Sood, Occult hepatitis B virus infection: a covert operation. Journal of Viral Hepatitis . vol .17(1), pp. 1-15, 2010.

[51] M.Meidani. Screening and evaluation of chronic and occult Hepatitis B in chemo-radiotherapy 
patients with cancer. Advanced biomedical research . vol .5, pp. $85,2016$.

[52] Burdick, R.A., Patterns of hepatitis B prevalence and seroconversion in hemodialysis units from three continents: the DOPPS. Kidney international . vol .63(6), pp. 2222-2229, 2003.

[53]F.Zoulim, , Hepatitis C virus infection in special groups. J Hepato .vol . 131 Suppl 1,pp. 130-5, 1999.

[54] Mahdavi, M.M., Hepatitis B Infection in hemodialysis patients in Tehran province, Iran,vol.14,pp.197-199,2009.

[55] Seo, D.H., Occult hepatitis B virus infection and blood transfusion. World J Hepato . vol .17(3),pp. 600-6, 2015.

[56] Makvandi, M., Update on occult hepatitis B virus infection. World Journal of Gastroenterology . vol .22(39),pp. $8720,2016$.

[57] G.L.-H.Wong, . Risk of hepatitis B surface antigen seroreversion after corticosteroid treatment in patients with previous hepatitis B virus exposure. Journal of hepatology . vol .72(1),pp.57-66, 2020.

[58]Ray, L., A comparative study of serum aminotransferases in chronic kidney disease with and without end-stage renal disease: Need for new reference ranges. International Journal of
Applied and Basic Medical Research . vol $.5(1)$, pp. $31,2015$.

[59] D.R.Crawford, , R.S. Reyna, and M.W. Weiner, Effects of in vivo and in vitro dialysis on plasma transaminase activity. Nephron . vol .22(46),pp.418-422, 1978

[60] K.Ono, , T. Ono, and T. Matsumata, The pathogenesis of decreased aspartate aminotransferase and alanine aminotransferase activity in the plasma of hemodialysis patients: the role of vitamin B6 deficiency. Clinical nephrology. Vol .43(6),pp. 405-408, 1995.

[61] T. Rampino . Hemodialysis prevents liver disease caused by hepatitis $\mathrm{C}$ virus: role of hepatocyte growth factor. Kidney international. Vol . 56(6),pp. 2286-2291,1999.

[62] C.P.Kovesdy . Outcome predictability of serum alkaline phosphatase in men with pre-dialysis CKD. Nephrology Dialysis Transplantation . vol .25(9), pp. 3003-3011, 2010.

[63] M.I.S. Kakey, and K.K. Abdoulrahman. Estimation of liver parameters and oxidative stress in chronic renal failure patients on hemodialysis in Erbil governorate. in AIP Conference Proceedings. AIP Publishing ,vol.13,pp.147-149,2017. 